\title{
Sparing Land for Biodiversity at Multiple Spatial Scales
}

\author{
Johan Ekroos ${ }^{1 *}$, Anja M. Ödman ${ }^{1,2}$, Georg K. S. Andersson ${ }^{1,2+}$, Klaus Birkhofer ${ }^{2}$, \\ Lina Herbertsson ${ }^{1}$, Björn K. Klatt ${ }^{1}$, Ola Olsson ${ }^{2}$, Pål Axel Olsson ${ }^{2}$, Anna S. Persson ${ }^{2}$, \\ Honor C. Prentice ${ }^{2}$, Maj Rundlöf ${ }^{2}$ and Henrik G. Smith ${ }^{1,2}$ \\ ${ }^{1}$ Centre for Environmental and Climate Research, Lund University, Lund, Sweden, ${ }^{2}$ Department of Biology, Lund University, \\ Lund, Sweden
}

OPEN ACCESS

Edited by:

Evangelia G. Drakou,

University of West Brittany, France

Reviewed by:

Jayanta Kumar Patra Yeungnam University, South Korea James Gilroy,

University of East Anglia, UK Ben Phalan,

University of Cambridge, UK

${ }^{*}$ Correspondence: Johan Ekroos

johan.ekroos@cec.lu.se; jeekroos@gmail.com

${ }^{\dagger}$ Present Address:

Georg K. S. Andersson,

Grupo de Investigación en

Agroecología (AGRECO), Sede Andina, Universidad Nacional de Río Negro, San Carlos de Bariloche, Argentina

Specialty section:

This article was submitted to Agroecology and Land Use Systems,

a section of the journal

Frontiers in Ecology and Evolution

Received: 28 August 2015 Accepted: 08 December 2015

Published: 05 January 2016

Citation:

Ekroos J, Ödman AM, Andersson GKS, Birkhofer K, Herbertsson L, Klatt BK, Olsson O, Olsson PA, Persson AS, Prentice HC,

Rundlöf M and Smith HG (2016)

Sparing Land for Biodiversity at Multiple Spatial Scales.

Front. Ecol. Evol. 3:145.

doi: 10.3389/fevo.2015.00145
A common approach to the conservation of farmland biodiversity and the promotion of multifunctional landscapes, particularly in landscapes containing only small remnants of non-crop habitats, has been to maintain landscape heterogeneity and reduce land-use intensity. In contrast, it has recently been shown that devoting specific areas of non-crop habitats to conservation, segregated from high-yielding farmland ("land sparing"), can more effectively conserve biodiversity than promoting low-yielding, less intensively managed farmland occupying larger areas ("land sharing"). In the present paper we suggest that the debate over the relative merits of land sparing or land sharing is partly blurred by the differing spatial scales at which it is suggested that land sparing should be applied. We argue that there is no single correct spatial scale for segregating biodiversity protection and commodity production in multifunctional landscapes. Instead we propose an alternative conceptual construct, which we call "multiple-scale land sparing," targeting biodiversity and ecosystem services in transformed landscapes. We discuss how multiple-scale land sparing may overcome the apparent dichotomy between land sharing and land sparing and help to find acceptable compromises that conserve biodiversity and landscape multifunctionality.

Keywords: central-place foraging, metapopulation, protected area, habitat patch network, landscape complementation, landscape mosaic

\section{INTRODUCTION}

Agricultural intensification and expansion have caused major losses of global biodiversity leading to fundamental trade-offs between food production and species conservation (Mattison and Norris, 2005). Strategies that preserve landscape heterogeneity and reduce agricultural land-use intensity are commonly used to conserve farmland biodiversity (Benton et al., 2003) and promote multifunctional landscapes (Foley et al., 2005). However, less intensive agricultural practices, such as organic farming, are often associated with reduced yields (Seufert et al., 2012; but see Ponisio et al., 2015), and in addition, it is not clear if such schemes generate aggregated biodiversity benefits at larger spatial scales (Kleijn et al., 2011; Birkhofer et al., 2014; Schneider et al., 2014). Recent research suggests that agricultural production needs to increase dramatically to feed globally increasing human populations, coupled with expected dietary shifts (Valin et al., 2014). It has been suggested that increased production could be achieved by closing yield gaps by, for example, increasing yields on existing farmland through optimized inputs of mineral nutrients (Foley et al., 2011; Mueller et al., 2012). However, other studies emphasize that, rather than focussing 
solely on increased production, there is a need to consider alternative ways of improving food security: reduction of food waste, reduction of the demand for livestock feed, and achieving an equitable distribution of the food that is currently produced (Fischer et al., 2014; Loos et al., 2014). Nevertheless, the conflicts between biodiversity protection and food production appear to be stronger than ever before.

By conceptualizing two contrasting land-use scenarios; land sparing and land sharing, it has been suggested that tradeoffs between biodiversity and food production are more likely to be alleviated by the spatial segregation of food production and conservation, which would allow for higher yields within smaller shares of lands (Green et al., 2005; Phalan et al., 2011a,b; Balmford et al., 2012). A land-sparing approach has been suggested to be particularly suitable in the tropics, where forests with high biodiversity values are threatened by expanding agriculture (Ramankutty and Rhemtulla, 2012). A complete segregation of land areas devoted to commodity production and biodiversity protection has nevertheless been criticized for two ecological reasons. First, the fact that a large proportion of species of conservation concern occur outside protected areas, also necessitates conservation strategies within production land (including both farmland and managed forests; Rodrigues et al., 2004; Palomo et al., 2014; Troupin and Carmel, 2014). Second, segregation strategies may increase negative off-site effects from intensive agriculture (Foley et al., 2005) and erode ecosystem services within agricultural systems-ultimately affecting yields and hindering the development of ecologically sustainable, highyielding farming systems (Bommarco et al., 2013).

Land sparing and land sharing are broadly defined as, respectively, segregating or integrating commodity production (e.g., agricultural production) and biodiversity protection. The production side in this relationship has been conceptualized by comparing landscapes along landscape-wide gradients of agricultural yields and baseline habitats with no yields (Phalan et al., 2011a,b), by exemplifying "land sparing" and "land sharing" with particular habitat types along land-use intensity gradients (e.g., Egan and Mortensen, 2012; Quinn et al., 2012), or by combinations of these approaches (Gabriel et al., 2013; Gilroy et al., 2014). However, particularly in relation to the latter two approaches, there is a wide variation in definitions of what constitutes spared land. While some researchers argue that only natural or near-natural habitats should be used to represent landsparing strategies (Phalan et al., 2011a), others have used grazed grasslands (Dotta et al., 2015; Kamp et al., 2015), or managed grasslands, set-asides, and field boundaries (Quinn et al., 2012; Gabriel et al., 2013), to represent land sparing. A similar variability in definitions also complicates the interpretation of what could constitute land sharing, which has been exemplified by organic farming (Hodgson et al., 2010; Gabriel et al., 2013), shade coffee (Chandler et al., 2013), silvopastures (Macchi et al., 2013), or landscapes with low human population densities (Chapron et al., 2014). In addition, while some researchers argue that land sparing must be carried out across large areas if it is to benefit biodiversity conservation (Phalan et al., 2011a), others have advocated that land sparing can be applied successfully at relatively small spatial scales (Gabriel et al., 2013).
In the present paper we suggest that the debate over the relative merits of land sparing or land sharing (Phalan et al., 2011a; Tscharntke et al., 2012a; Fischer et al., 2014) is partly blurred by the differing spatial scales at which it is suggested land sparing should be applied. Neither sparing nor sharing is conceptually tied to a particular scale, creating a definitional gray zone (Fischer et al., 2014) and making it challenging to generalize outcomes between land sparing and land sharing across different contexts. Despite this, it is clear that conservation efforts are needed at multiple spatial scales both in general (Lindenmayer et al., 2006) and, more specifically in agricultural landscapes (Benton et al., 2003; Fischer et al., 2008).

To allow a discussion of multiple scale sparing strategies, we explicitly define land sparing as delimiting habitats known or supposed to be important for biodiversity and land primarily devoted to commodity production, irrespective of the spatial scale at which this is carried out. The spared land may thus constitute larger reserves (Phalan et al., 2011b), more finegrained habitat fragments (Hodgson et al., 2010), or at even smaller spatial scales, field boundaries (Gabriel et al., 2013). The framework of land sparing vs. land sharing can be applied for any production system (Edwards et al., 2014; Paul and Knoke, 2015; Stott et al., 2015), but here we focus on trade-offs between agricultural production and biodiversity conservation. We define land sharing as any intervention intended to benefit biodiversity by reducing in-field agricultural intensity, for example by reducing stocking rates in pastures and the use of agro-chemicals in arable fields, which therefore reduces yields compared to a baseline of intensive agricultural production. However, we are fully aware that in practice there may be cases where it is debatable whether a specific measure constitutes sharing or sparing (e.g., integrated pest management, when long-term setasides are established on arable land, or when spared land needs low-intensive agricultural management to maintain biodiversity). We highlight the need for maintaining biodiversity-friendly habitats over a hierarchy of spatial scales (Figure 1) in order to conserve biodiversity and to benefit ecosystem services relevant for agricultural production (Bommarco et al., 2013; Ekroos et al., 2014). Finally, we discuss whether multiplescale land sparing is sufficient to reach these goals, or whether land sharing may additionally be needed in some circumstances.

\section{BIODIVERSITY CONSERVATION ACROSS MULTIPLE SPATIAL SCALES}

Conservation at different spatial scales is necessary because conservation has multiple objectives, which range from the conservation of wide-ranging iconic species to the integration of functional biodiversity within production landscapes (Mace et al., 2012). Traditional conservation has a focus on sparing specific areas that are known to be important for species in need of conservation efforts, or on distinct habitat types that form the basis for current biodiversity protection schemes (Secretariat of the Convention of Biological Diversity, 2008). 


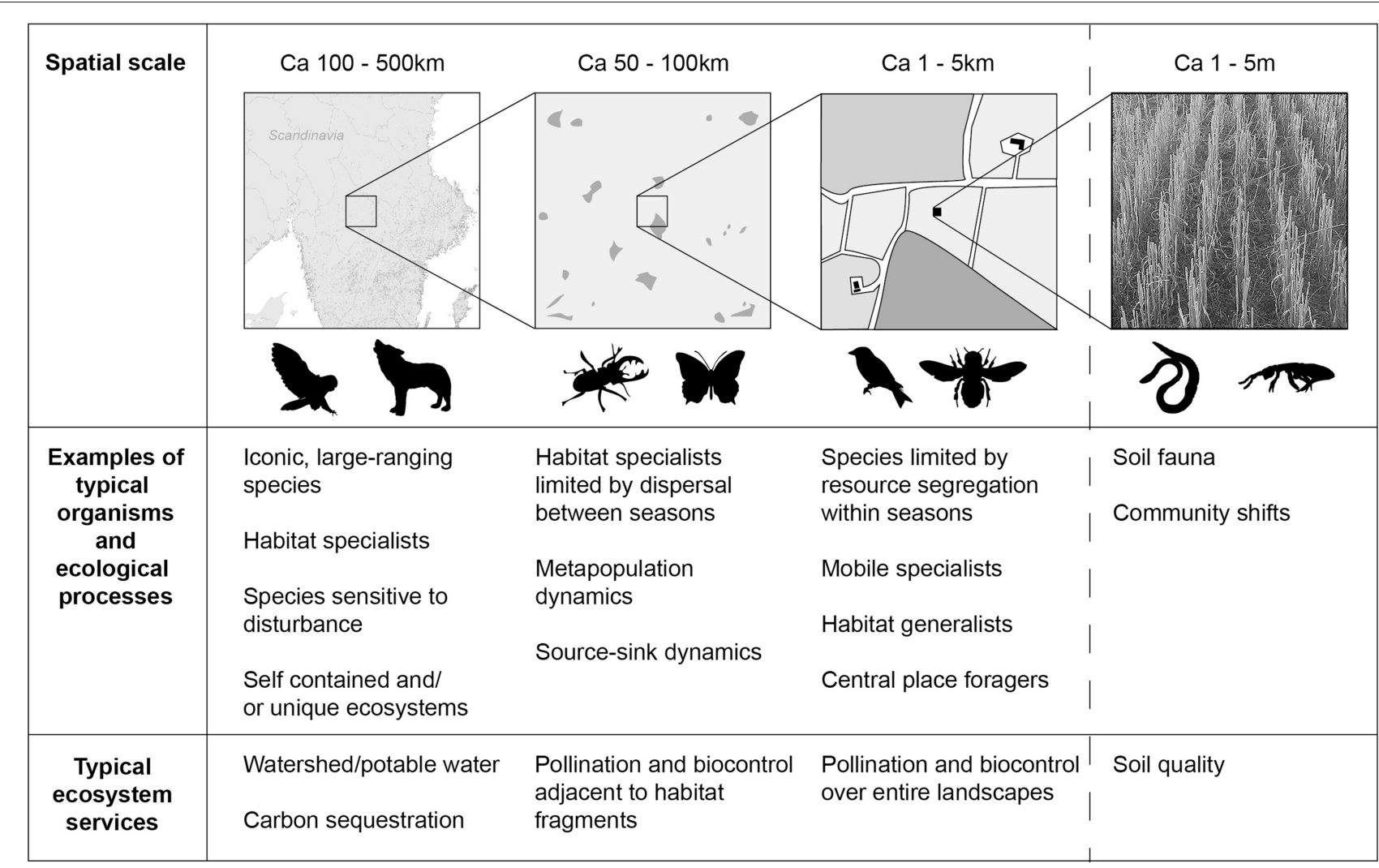

FIGURE 1 | A simplistic representation of spatial scales at which ecological processes modulating biodiversity and multiple ecosystem services operate. Nature reserves can effectively protect species (e.g., iconic, large-ranging mammals) that are sensitive to anthropogenic disturbance, whereas dispersal-limited species (e.g., strict habitat specialists) occurring in highly fragmented landscapes benefit from conservation efforts based on sparing habitat-patch networks across smaller regions. At smaller spatial scales, many mobile habitat specialists and habitat generalists occurring in farmland will benefit from sparing key resource patches integrated across landscape mosaics spanning a few kilometers, as long as resource patches for the particular species are found within their foraging range. Many ecosystem services, such as carbon sequestration across large spatial scales, and services relying on mobile organisms at smaller spatial scales, may also be governed by sparing habitats at spatial scales corresponding to those presented above. Soil quality in production lands is, however, underpinned by the local soil biota and cannot benefit from land-sparing strategies. Instead, improving soil quality must rely on interventions implemented within individual fields.

However, conservation efforts at large spatial scales need to be complemented by conservation efforts at smaller, more fine-grained, spatial scales. In human-modified landscapes the opportunities for conservation are set by historical land-use, and opportunities for sparing large areas of land may not be a practical alternative. While conservation at large spatial scales creates areas with a high degree of ecological integrity, conservation at smaller spatial scales may facilitate the dispersal of organisms between fragmented habitats (Honnay et al., 2002), or provide complementary resources for mobile species (Smith et al., 2014). Below we therefore also illustrate how sparing at two smaller spatial scales affect two distinct ecological processes of importance for biodiversity conservation. At regional scales, metapopulation dynamics govern spatially structured populations, because local populations face significant risk of extinction, whereas at smaller spatial scales, processes affecting regular foraging movements of animals in landscape mosaics, determine population persistence (see Figure 1).

\section{SPARING HABITAT AT LARGE SPATIAL SCALES: CONTIGUOUS PROTECTED AREAS}

Protected areas constitute the backbone of traditional nature conservation efforts (Baudron and Giller, 2014), with over 12\% of the world's total land area currently under some form of formal protection (Joppa and Pfaff, 2011). The argument for focussing conservation efforts on large, contiguous nature reserves is supported by ecological theory: the concept of minimum viable population size suggests that the success of an effort to conserve a threatened species is likely to increase with increasing population size (Frankham et al., 2014), while the species-area relationship predicts that species richness will increase with increasing area and increasing habitat diversity (Rosenzweig, 1995). In addition, the ecological integrity of a reserve is more likely to remain intact with increasing reserve area and habitat diversity (Schwartz, 1999). However, as further discussed below, a network of small reserves with a small total area may also capture a high overall 
level of diversity in some cases (Tscharntke et al., 2012b). Such observations have led some researchers to question the anticipated strong negative effects of habitat fragmentation on biodiversity (Fahrig, 2013), whereas others point out that simple estimates of species richness provide a poor basis for effective biodiversity conservation (Phalan et al., 2011a; Hanski, 2015).

To efficiently protect species within protected areas, these should be large enough to maintain ecological integrity and cover representative habitat types over large geographic areas. Protected areas have historically not been designated on the basis of ecological integrity, but instead on factors such as scenic, recreational or hunting value, or the protection of large-ranging iconic species (Pressey, 1994; Scott et al., 2001). Furthermore, because of the high opportunity costs of conservation in production landscapes, most protected areas lie in regions with low productivity and, as a consequence, these protected areas are likely to target only a subset of the overall regional diversity (Joppa and Pfaff, 2011). In Europe the Habitats Directive (European Commission, 1992) and the Birds Directive (European Commission, 2009) forms a binding legislative framework for creating a network of protected areas identified across large geographic scales (the Natura 2000 network). The Natura 2000 network has been found to perform better compared to nationally designated protected areas (Sánchez-Fernández et al., 2013), but substantial gaps have also been identified (D’Amen et al., 2013; Maiorano et al., 2015; Sánchez-Fernández and Abellán, 2015). In addition, although protected areas may be large enough to contain multiple habitats and ecosystems, they often do not include all necessary habitat elements required to maintain natural disturbance regimes, nutrient flows, organism movements, and population processes within them (Hansen and DeFries, 2007; Wiens, 2009).

\section{SPARING HABITAT AT REGIONAL SCALES: HABITAT PATCH NETWORKS}

Strict habitat specialists are dependent on a particular type of habitat and, because of land-use change, many such habitats are currently highly fragmented (Hanski, 2005; Tscharntke et al., 2012b). Individual habitat fragments are often not large enough to sustain viable populations, particularly in the absence of immigration. In such situations, protecting networks of remaining habitat fragments across entire regions becomes essential for the maintenance of long-term population viability. Rare but recurrent dispersal events between habitat fragments are a typical feature of metapopulation dynamics (Fronhofer et al., 2012) and may play a particularly important role for habitat specialists that occur in highly fragmented landscapes, such as semi-natural grassland in Central Europe (Tscharntke et al., 2012b) or old-growth forests (Hanski, 2005). A metapopulation can form when the environment is structurally highly variable, and when between-patch movement is possible, yet much reduced by dispersal barriers (Fronhofer et al., 2012). The bestknown empirical example of a metapopulation is provided by the Glanville Fritillary (Melitaea cinxia) on the Alland Islands, where the butterfly occurs in highly fragmented dry grasslands.
The $\sim 1600$ grassland fragments are located within an area of roughly $75 \times 50 \mathrm{~km}^{2}$, covering only around $2 \mathrm{~km}^{2}$ altogether (Ojanen et al., 2013).

Poor dispersal, for example limited seed dispersal in plants, may reduce the ability of species to colonize available patches of suitable habitat (Riibak et al., 2015). For example, plant population sizes and levels of genetic diversity are often positively related to historically less fragmented landscapes. Grassland plants are therefore often characterized by an extinction debt leading to further losses of species, even though there is no further habitat fragmentation (Kuussaari et al., 2009). Sparing habitat fragments across regions in a way that takes into account the historical distribution of habitat fragments as well as current dispersal probabilities between local populations may therefore be critically important to maximize and maintain overall diversity. In Europe, grassland habitat specialists are often restricted to sites that have had a prolonged history of grazing and nutrient-removal (Purschke et al., 2013). Such sites, which have had hundreds of years of grazing continuity, can therefore not be substituted by young patches of nutrient-rich grassland habitat.

\section{SPARING HABITATS IN LANDSCAPE MOSAICS}

Many animals, including species that are relatively specialized in their habitat and resource use, are mobile enough to persist within mosaic landscapes that consist of multiple distinct habitat patches, separated by distances of tens to thousands of meters. In some cases organisms have to use resources in multiple patches for populations to be viable (landscape complementation and supplementation sensu Dunning et al., 1992). In contrast to habitat patch networks, where migration events between patches are rare because of dispersal limitation, habitat mosaics are characterized by regular movements between habitat patches, either within seasons (e.g., spill-over processes) or within days (e.g., multipatch foraging; Tscharntke et al., 2005; Fahrig et al., 2011; Blitzer et al., 2012; Smith et al., 2014). Many relatively common organisms use multiple habitats that offer complementary or supplementary resources, and therefore perceive landscapes as mosaics consisting of habitat patches varying in quality over space and time (Fahrig et al., 2011; Tscharntke et al., 2012b). The habitat patches of the mosaic landscape are used by animals for separate needs, such as food, shelter, nesting, and/or hibernation (Fahrig et al., 2011). Although the need for between-patch movement may vary over the day or over the season, unconstrained and regular movement is fundamentally important for species to be able to persist in mosaic landscapes.

Daily movements are particularly important for the shortterm persistence of central-place foragers, such as birds and nest-building insects, which often feed in multiple habitat patches that together sustain populations through landscape complementation and/or landscape supplementation processes (Olsson and Bolin, 2014; Smith et al., 2014). Bumble bees nesting in semi-natural habitats regularly fly out into the surrounding agricultural landscape to forage in other, more flower rich 
habitats (Öckinger and Smith, 2007; Garibaldi et al., 2011; Ekroos et al., 2013). Some species forage over large areas and are thus able to utilize spatially scattered resources, including highly rewarding, but seasonally restricted resources such as mass-flowering crops (Garibaldi et al., 2011; Rundlöf et al., 2014). Therefore, preserving key habitat features offering nesting and feeding sites at a scale within daily or seasonal movement ranges will be important to promote biodiversity in mosaic landscapes, such as farmland (Smith et al., 2014) or forestry systems (Lindenmayer et al., 2006).

\section{MULTIPLE-SCALE SPARING AND SOFTENING THE MATRIX}

A multiple-scale land-sparing approach has the potential to benefit biodiversity beyond the specific spatial scales discussed above. In particular, sparing habitats at smaller spatial scales may benefit biodiversity at larger spatial scales by increasing resource availability for organisms that fundamentally depend on larger-scale habitat-patch networks. While conservation has traditionally focused on creating fairly large reserves on the basis, for example, of species-area relations or the aim of maximizing carrying capacity (e.g., Palomo et al., 2014), such approaches might not be practically feasible in heavily fragmented agricultural landscapes (Koh et al., 2009; Perfecto and Vandermeer, 2010). Thus, small-scale land sparing may increase the quality of the matrix surrounding biodiversity-rich patches and thereby deliver substantial biodiversity benefits (Ricketts, 2001; Fischer et al., 2006; Driscoll et al., 2013). A multiplescale land sparing framework also has the potential of mitigating disruptions in symbiotic interactions in habitats of conservation concern by improving the quality of the surrounding landscapes (Pauw, 2007; Emer et al., 2013; Clough et al., 2014).

In Europe, semi-natural grasslands embedded in agricultural landscapes are highly species-rich and include many species of conservation concern (Steffan-Dewenter et al., 2014). Creating or managing field boundaries, woodlots or ponds, represent small-scale land-sparing options that might benefit grassland biodiversity across larger spatial scales by reducing the hostility of the landscape matrix (Donald and Evans, 2006). Thus, integrating conservation interventions in the form of a network of natural or semi-natural areas across agricultural landscapes (i.e., green infrastructure, see Maes et al., 2015) could benefit a range of species not primarily occurring in intensively managed farmland (Bergman et al., 2004; Öckinger and Smith, 2006, 2008).

However, while it has been argued that the integration of conservation strategies across landscapes is particularly important in the face of the dual threats of increasing landuse intensity and climate change (Hannah et al., 2002; Gillson et al., 2013), there are diverging views on how to achieve conservation goals. It has been suggested that improving habitats themselves, either quantitatively or qualitatively, offers a more effective conservation strategy compared with strategies that target the surrounding matrix (Hodgson et al., 2009, 2011). However, in particular in agricultural landscapes with fertile soils and hence high productivity, it might not be feasible to expand source habitats because of high opportunity costs, in which case incentives targeting the matrix might be the only practical solution (Ekroos et al., 2014). Nevertheless, efforts to enhance the quality of the matrix for conservation are similarly constrained by high opportunity costs of any interventions that reduce yields. A combination of maintaining existing habitat fragments and creating small, high-quality grassland patches or resource-rich non-crop habitats between fields might, depending on landscape context, be the most effective strategy to promote biodiversity in highly fragmented agricultural landscapes (Baum et al., 2004; Rösch et al., 2013). The relative effectiveness of improving local habitat quality in fragments vs. improving matrix quality is likely to be highly context-dependent. Both perspectives offer hypotheses that can be tested in order to identify suitable strategies for specific conservation objectives.

\section{MULTIPLE-SCALE SPARING AND ECOLOGICALLY SUSTAINABLE AGRICULTURE}

In addition to food, feed and biofuels, agricultural systems play an important role in water and climate regulation, and the cycling and retention of nutrients (Norris et al., 2010). Agriculture is also ultimately dependent on a range of ecosystem processes that need to be accounted for in land-use decisions. Intensive agriculture that relies on high external inputs in terms of fertilizers and pesticides erodes ecosystem functions such as pollination, biological pest control, and nutrient cycling, which to a large extent rely on species commonly occurring in farmland (Tilman et al., 2002; Gaston and Fuller, 2008). So-called ecological intensification has been suggested as a means of increasing the sustainability of farming (Bommarco et al., 2013) by maintaining high yields through an increasing reliance on biodiversity-based ecosystem functions, or intermediate ecosystem services (Fisher et al., 2009). The challenge is to match the occurrence of beneficial biodiversity with the demand of the services provided by pollinating insects, predatory insects, or soil fauna, which in part depend on the spatial scale at which habitats are integrated across production lands (Mitchell et al., 2015). In the following we discuss how these demands can be met within the context of multiple-scale land sparing.

Important ecosystem service providers, such as pollinators and biological pest control agents, can be maintained by employing strategic interventions integrated within production lands (cf. Mitchell et al., 2015). Bees are central-place foragers that nest in various non-crop habitats and forage in local flowerrich habitats within their home-range. Because of their huge variety of life histories and ecological traits bee communities respond to land-use changes across multiple spatial scales. At local spatial scales, the disconnection between non-crop habitats, which provide nest sites for bees, and fields with insect-pollinated crops, can affect pollination services by wild bees and thereby crop yield. In contrast, pollination services provided by feral honey bees remain unaffected in such conditions (Garibaldi et al., 2011). Therefore, a land sparing strategy to promote wild pollinators should integrate non-crop habitat patches 
evenly across production lands to ensure that insect-pollinated crops are located within the foraging range of pollinating insects. In addition, a greater proportion of natural habitats in the landscape can buffer wild bee communities from local impairments caused by pesticides (Park et al., 2015). Enhancing pollination services as such does not necessarily benefit rare species with specific habitat requirements (Kleijn et al., 2015). However, some important habitats for habitat specialists, such as semi-natural grasslands, also provide important nesting sites for pollinators, creating possible synergies between biodiversity conservation and ecosystem service provisioning (Macfadyen et al., 2012; Ekroos et al., 2014). The extent to which pollination in agricultural landscapes coincides with the occurrence of habitats targeting species of conservation concern is generally not known. Neither is it known whether there is a relationship between local habitat quality in semi-natural grasslands and pollination in the surrounding agricultural landscapes. With the loss of semi-natural grasslands the importance of sparing habitats at smaller spatial scales, such as non-crop field boundaries, increase, as they may provide substantial benefits for pollinating insects (Benjamin et al., 2014), although grassland habitat specialists are not likely to persist in such landscapes (Ekroos and Kuussaari, 2012).

In contrast to wild bees, generalist arthropod predators are not restricted to a local nest site and its surroundings. Instead, local assemblages of generalist predators are affected by the degree of disturbance of the local habitat (field), where land-use intensification represents increased disturbance and translates into less diverse predator communities (Rusch et al., 2014). Increasing non-crop habitat heterogeneity of the surrounding landscapes may alleviate this effect, where spared habitats act as source habitats through spill-over effects (Blitzer et al., 2012) or mass-effects (Leibold et al., 2004). A multiple-scale land-sparing approach will affect the landscape context surrounding local fields, which in turn can be managed with in-field interventions. To enhance biological pest control it becomes crucial to consider the interactions between in-field scale practices and larger scale changes of landscape composition for ecosystem services and service-providing units (Jonsson et al., 2014). Increasing landscape complexity by sparing non-crop habitats may, for example, affect parasitism rates of agricultural pests positively (Jonsson et al., 2012) or negatively (Menalled et al., 2003). This variability of the relationships between biological control and landscape complexity partly stems from variation in the effect of local farming practices on natural enemy and pest abundances (Rusch et al., 2010). It has therefore been suggested that in-field management interventions have the highest potential to promote biological control services in landscapes that provide little or no alternative non-crop habitats (Tscharntke et al., 2005).

In contrast to pollination services and biological pest control, the process of nutrient cycling cannot be segregated from production land in a meaningful way if it is to benefit arable production. The maintenance of soil fertility is essential for the long-term sustainability of agriculture, which demands management actions that enhance soil biodiversity at the level of individual fields (Figure 1). Nevertheless, the soil quality of arable land has been declining for decades in Europe, which is worrying in terms of the sustainability of food production (Verheijen et al., 2009; JRC, 2012). Maintaining nutrient-rich top soils in agricultural land is important for increasing resistance to erosion, water-holding capacity, and soil fertility (Boardman, 2013). Because soil quality can only be managed at the local scale (Tscharntke et al., 2012b), a multiple-scale land-sparing approach cannot substitute in-field measures to decrease landuse intensity, such as using organic fertilizers, less intensive tillage practices, including legumes into crop rotations, or introducing rotational set-asides (Norris et al., 2010; Quinn et al., 2012).

\section{PROSPECTS AND CONCLUSIONS}

In this paper we have argued that land sparing should be seen as a strategy to be implemented simultaneously at multiple spatial scales. In transformed landscapes, only a multiple-scale approach can consider all the major ecological processes that determine levels of biodiversity, affecting habitat specialists and species of conservation concern across regions and common species essential for ecosystem functioning locally, on individual farms. The approach could operationalized using a two-tiered approach: (1) on single farms, or amongst a group of collaborating farms, implement management strategies that increase, or maintain a heterogeneous landscape mosaic, and (2) on the basis of regional assessments of habitat availability and connectivity, create incentives for landowners to maintain specific habitats that are important for species of conservation concern (e.g., forests and forest remnants, semi-natural grasslands). Land-use decisions in landscapes dominated by farmland would, therefore, be made by farmers (guided by agri-environment schemes targeting key ecosystem processes) whereas biodiversity conservation should rely on identifying key landscape elements across larger spatial scales. Landscape elements identified as important for biodiversity conservation could thereafter be included as targeted measures within agri-environment schemes, which is currently the case e.g., in Sweden, regarding management of species-rich semi-natural pastures (Jordbruksverket, 2005). We believe that a multi-scale sparing approach offers the opportunity of combining biodiversity conservation with the ecological intensification of agriculture (Bommarco et al., 2013; Pywell et al., 2015), which will be needed if we are to produce increasing amounts of food and, simultaneously, decrease negative externalities of agriculture (Geiger et al., 2010; Vörösmarty et al., 2010; Rundlöf et al., 2015; Stehle and Schultz, 2015) while maintaining agricultural soil quality (Verheijen et al., 2009).

However, we also acknowledge that trade-offs may appear if investing resources in sparing habitats at one spatial scale reduces resources or opportunities for sparing habitat at other spatial scales. Given a fixed budget, trade-offs between e.g., buying land for a new nature reserve and financing small-scale habitat restoration in farmland under CAP obligations could potentially arise. Similarly trade-offs might arise between the goals of protecting biodiversity for its own sake vs. enhancing ecosystem service providers. For example, restoring habitats for grassland specialists may demand costly restoration interventions (Olsson and Ödman, 2014), whereas enhancing populations of ecosystem service providers could be effective with completely different 
management interventions such as flower strips (Kleijn et al., 2015). The relative weighting of efforts at various spatial scales is a complicated issue that will depend on both the prioritization of different conservation goals and on the prevailing ecological conditions such as soil productivity, the strength of the links between service-providing organisms and yields (Ekroos et al., 2014), and whether synergies emerge between multiple-scale land-sparing interventions through e.g., source-sink dynamics between regions or habitats (Diffendorfer, 1998).

The amount of land that needs to be spared at various spatial scales remains an open question for future research. Across landscape mosaics only a few species persists when the proportion of semi-natural habitat is less than a few percentages (Tscharntke et al., 2005), although many of these are common species that are important providers of ecosystem services (Kleijn et al., 2015). There is little information on the landscape conditions under which ecosystem service provisioning varies over time (Bommarco et al., 2013; Fremier et al., 2013; Birkhofer et al., 2015), although we can expect a higher variability in ecosystem service flows over time in structurally simplified landscapes (Bengtsson et al., 2003; Tscharntke et al., 2012b). In addition, it is currently not well-known to what extent land sparing in landscape mosaics can replace in-field interventions, such as organic farming, to benefit local biodiversity (c.f. Gonthier et al., 2014).

There is not a single answer to the question of how much habitat needs to be spared at the level of habitat patch networks as species will differ strongly in their dispersal ability and tolerance of habitat degradation, including edge effects (Hanski, 2011, 2015). Reconciling biodiversity conservation and commodity production may therefore be particularly challenging at a regional scale in highly fragmented landscapes. On a longer timescale, restoration of degraded land (Law and Wilson, 2015) or the rewilding of abandoned land (Navarro and Pereira, 2012; Ceauşu et al., 2015) may provide new ways of increasing structural heterogeneity within landscape mosaics or habitat availability and level of connectivity across landscapes. Finally, at national or continental levels, it will be important to identify areas of particular importance for biodiversity to complement the selection of currently protected areas and minimize conflicts between agriculture and conservation. Shackelford et al. (2015) recently showed how such conflicts could be minimized on a global scale, with a focus on regions where agricultural expansion may take place at the expense of forest biodiversity, and where

\section{REFERENCES}

Balmford, A., Green, R., and Phalan, B. (2012). What conservationists need to know about farming. Proc. R. Soc. B 279, 2714-2724. doi: 10.1098/rspb.2012.0515

Baudron, F., and Giller, K. E. (2014). Agriculture and nature: trouble and strife? Biol. Conserv. 170, 232-245. doi: 10.1016/j.biocon.2013.12.009

Baum, K. A., Haynes, K. J., Dillemuth, F. P., and Cronin, J. T. (2004). The matrix enhances the effectiveness of corridors and stepping stones. Ecology 85, 2671-2675. doi: 10.1890/04-0500

Bengtsson, J., Angelstam, P., Elmqvist, T., Emanuelsson, U., Folke, C., Ihse, M., et al. (2003). Reserves, resilience and dynamic landscapes. Ambio 32, 389-396. doi: 10.1579/0044-7447-32.6.389 increasing local land-use intensity (i.e., closing yield gaps) might threaten, for example, red-listed farmland or grassland species.

Trade-offs between biodiversity and agricultural production have spurred recent research on the relative benefits of land sparing and land sharing (Kremen, 2015). Given our definition of multiple-scale land sparing, the majority of studies seeking to reconcile biodiversity conservation with agricultural production have found land sparing to be the optimal solution (see e.g., von Wehrden et al., 2014). Irrespective of definitions, achieving efficient interventions and governance structures for land sparing at multiple scales will be challenging (Grau et al., 2013; Fischer et al., 2014). In Europe, designing interventions would call for close integration of small-scale land-sparing incentives which are currently governed by the EU Common Agricultural Policy, together with conservation efforts, such as the Natura 2000 network, implemented at larger spatial scales. Because agricultural production is becoming increasingly important on a global scale it will be crucial to identify the conservation strategies that return the greatest amount of biodiversity without compromising production (Phalan et al., 2011b). Using a multi-scale land sparing framework to solve trade-offs between biodiversity and production would ultimately demand that conservation strategies would be identified using e.g. efficiency frontiers optimizing production and levels of biodiversity at various spatial scales (Ekroos et al., 2014; Fischer et al., 2014; Butsic and Kuemmerle, 2015). Strategies are likely to be highly context-dependent as a consequence of regional variation in the types of habitat that are available for biodiversity and the soil fertility that determine the potential for arable production (Ekroos et al., 2014; Shackelford et al., 2015). We believe the optimal strategy will be a multi-scale strategy which, given multiple goals of conservation, can take very different forms depending on regional characteristics.

\section{ACKNOWLEDGMENTS}

This paper is based on a series of interdisciplinary workshops held in Lund during 2013 and 2014, dealing with the consequences of land sparing at various spatial scales. We thank Mark Brady and Yann Clough for valuable input during the workshops. The research was supported by the strategic research environment BECC, the strong research environment SAPES funded by FORMAS, and by the Era-net project MULTAGRI.

Benjamin, F. E., Reilly, J. R., and Winfree, R. (2014). Pollinator body size mediates the scale at which land use drives crop pollination services. J. Appl. Ecol. 51, 440-449. doi: 10.1111/1365-2664.12198

Benton, T. G., Vickery, J. A., and Wilson, J. D. (2003). Farmland biodiversity: is habitat heterogeneity the key? Trends Ecol. Evol. 4, 182-188. doi: 10.1016/S0169-5347(03)00011-9

Bergman, K. O., Askling, J., Ekberg, O., Ignell, H., Wahlman, H., and Milberg, P. (2004). Landscape effects on butterfly assemblages in an agricultural region. Ecography 27, 619-628. doi: 10.1111/j.0906-7590.2004.03906.x

Birkhofer, K., Diehl, E., Andersson, J., Ekroos, J., Früh-Müller, A., Machnikowski, F., et al. (2015). Ecosystem services-current challenges and opportunities for ecological research. Front. Ecol. Evol. 2:87. doi: 10.3389/fevo.2014. 00087 
Birkhofer, K., Ekroos, J., Corlett, E. B., and Smith, H. G. (2014). Winners and losers of organic cereal farming in animal communities across central and Northern Europe. Biol. Conserv. 175, 25-33. doi: 10.1016/j.biocon.2014.04.014

Blitzer, E. J., Dormann, C. F., Holzschuh, A., Klein, A.-M., Rand, T. A., and Tscharntke, T. (2012). Spillover of functionally important organisms between managed and natural habitats. Agric. Ecosyst. Environ. 146, 34-43. doi: 10.1016/j.agee.2011.09.005

Boardman, J. (2013). Soil erosion in Britain: updating the record. Agriculture 3, 418-442. doi: 10.3390/agriculture3030418

Bommarco, R., Kleijn, D., and Potts, S. G. (2013). Ecological intensification: harnessing ecosystem services for food security. Trends Ecol. Evol. 28, 230-238. doi: $10.1016 /$ j.tree.2012.10.012

Butsic, V., and Kuemmerle, T. (2015). Using optimization methods to align food production and biodiversity conservation beyond land sharing and land sparing. Ecol. Appl. 25, 589-595. doi: 10.1890/14-1927.1

Ceauşu, S., Hofmann, M., Navarro, L. M., Carver, S., Verburg, P. H., and Pereira, H. M. (2015). Mapping opportunities and challenges for rewilding Europe. Conserv. Biol. 29, 1017-1027. doi: 10.1111/cobi.12533

Chandler, R. B., King, D. I., Raudales, R., Trubey, R., Chandler, C., and Chávez, V. J. A. (2013). A small-scale land-sparing approach to conserving biological diversity in tropical agricultural landscapes. Conserv. Biol. 27, 785-795. doi: 10.1111/cobi. 12046

Chapron, G., Kaczensky, P., Linnell, J. D. C., von Arx, M., Huber, D., Andrén, H., et al. (2014). Recovery of large carnivores in Europe's modern humandominated landscapes. Science 346, 1517-1519. doi: 10.1126/science.1257553

Clough, Y., Ekroos, J., Báldi, A., Batáry, P., Bommarco, R., Gross, N., et al. (2014). Density of insect-pollinated grassland plants decreases with increasing surrounding land-use intensity. Ecol. Lett. 17, 1168-1177. doi: 10.1111/ele.12325

D’Amen, M., Bombi, P., Campanaro, A., Zapponi, L., Bologna, M. A., and Mason, F. (2013). Protected areas and insect conservation: questioning the effectiveness of Natura 2000 network for saproxylic beetles. Anim. Conserv. 16, 370-378. doi: $10.1111 /$ acv. 12016

Diffendorfer, J. E. (1998). Testing models of source-sink dynamics and balanced dispersal. Oikos 81, 417-433. doi: 10.2307/3546763

Donald, P. F., and Evans, A. D. (2006). Habitat connectivity and matrix restoration: the wider implications of agri-environment schemes. J. Appl. Ecol. 43, 209-218. doi: 10.1111/j.1365-2664.2006.01146.x

Dotta, G., Phalan, B., Silva, T. W., Green, R., and Balmford, A. (2015). Assessing strategies to reconcile agriculture and bird conservation in the temperate grasslands of South America. Conserv. Biol. doi: 10.1111/cobi.12635. [Epub ahead of print].

Driscoll, D. A., Banks, S. C., Barton, P. S., Lindenmayer, D. B., and Smith, A. L. (2013). Conceptual domain of the matrix in fragmented landscapes. Trends Ecol. Evol. 28, 605-613. doi: 10.1016/j.tree.2013.06.010

Dunning, J. B., Danielson, B. J., and Pulliam, R. H. (1992). Ecological processes that affect populations in complex landscapes. Oikos 65, 169-175. doi: $10.2307 / 3544901$

Edwards, D. P., Gilroy, J. J., Woodcock, P., Edwards, F. A., Larsen, T. H., Andrews, D. J. R., et al. (2014). Land-sharing versus land-sparing logging: reconciling timber extraction with biodiversity conservation. Global Change Biol. 20, 183-191. doi: 10.1111/gcb.12353

Egan, J. F., and Mortensen, D. A. (2012). A comparison of land-sparing and landsharing strategies for plant richness conservation in agricultural landscapes. Ecol. Appl. 22, 459-471. doi: 10.1890/11-0206.1

Ekroos, J., and Kuussaari, M. (2012). Landscape context affects the relationship between local and landscape species richness of butterflies in semi-natural habitats. Ecography 34, 232-238. doi: 10.1111/j.1600-0587.2011.07005.x

Ekroos, J., Olsson, O., Rundlöf, M., Wätzold, F., and Smith, H. G. (2014). Optimizing agri-environment schemes for biodiversity, ecosystem services or both? Biol. Conserv. 172, 65-71. doi: 10.1016/j.biocon.2014.02.013

Ekroos, J., Rundlöf, M., and Smith, H. G. (2013). Trait-dependent responses of flower-visiting insects to distance to semi-natural grasslands and landscape heterogeneity. Landscape Ecol. 28, 1283-1292. doi: 10.1007/s10980-0139864-2

Emer, C., Venticinque, E. M., and Fonseca, C. R. (2013). Effects of dam-induced landscape fragmentation on Amazonian ant-plant mutualistic networks. Conserv. Biol. 27, 763-773. doi: 10.1111/cobi.12045
European Commission (1992). Council Directive 92/43/EEC of 21 May 1992 on the conservation of natural habitats and of wild fauna and flora. Official J. Eur. Union L 206, 7-50.

European Commission (2009). Directive 2009/147/EC of the European Parliament and of the Council of 30 November 2009 on the conservation of wild birds. Official J. Eur. Union L 20, 7-25.

Fahrig, L. (2013). Rethinking patch size and isolation effects: the habitat amount hypothesis. J. Biogeogr. 40, 1649-1663. doi: 10.1111/jbi.12130

Fahrig, L., Baudry, J., Brotons, L., Burel, F. G., Crist, T. O., Fuller, R. J., et al. (2011). Functional landscape heterogeneity and animal biodiversity in agricultural landscapes. Ecol. Lett. 14, 101-112. doi: 10.1111/j.1461-0248.2010.01559.x

Fischer, J., Abson, D. J., Butsic, V., Chappell, M. J., Ekroos, J., Hanspach, J., et al. (2014). Land sparing versus land sharing: moving forward. Conserv. Lett. 7 , 149-157. doi: 10.1111/conl.12084

Fischer, J., Brosi, B., Daily, G. C., Ehrlich, P. R., Goldman, R., Goldstein, J., et al. (2008). Should agricultural policies encourage land sparing or wildlife-friendly farmin? Front. Ecol. Environ. 6, 380-385. doi: 10.1890/070019

Fischer, J., Lindenmayer, D. B., and Manning, A. D. (2006). Biodiversity, ecosystem function and resilience: ten guiding principles for commodity production landscapes. Front. Ecol. Environ. 4, 80-86. doi: 10.1890/15409295(2006)004[0080:BEFART]2.0.CO;2

Fisher, B., Turner, R. K., and Morling, P. (2009). Defining and classifying ecosystem services for decision making. Ecol. Econom. 68, 643-653. doi: 10.1016/j.ecolecon.2008.09.014

Foley, J. A., Defries, R., Asner, G. P., Barford, C., Bonan, G., Carpenter, S. R., et al. (2005). Global consequences of land use. Science 309, 570-574. doi: $10.1126 /$ science. 1111772

Foley, J. A., Ramankutty, N., Brauman, K. A., Cassidy, E. S., Gerber, J. S., Johnston, M., et al. (2011). Solutions for a cultivated planet. Nature 478, 337-342. doi: 10.1038 /nature 10452

Frankham, R., Bradshaw, J. C. A., and Brook, B. W. (2014). Genetics in conservation management: revised recommendations for the 50/500 rules, red list criteria and population viability analyses. Biol. Conserv. 170, 56-63. doi: 10.1016/j.biocon.2013.12.036

Fremier, A. K., DeClerk, F. A. J., Bosque-Perez, N. A., Carmona, N. A., Hill, R., Joyal, T., et al. (2013). Understanding spatiotemporal lags in ecosystem services to improve incentives. Bioscience 63, 472-482. doi: 10.1525/bio.2013. 63.6 .9

Fronhofer, E. A., Kubish, A., Hilker, F. M., Hovestadt, T., and Poethke, H. J. (2012). Why are metapopulations so rare? Ecology 93, 1967-1978. doi: 10.1890/111814.1

Gabriel, D., Sait, S. M., Kunin, W. E., and Benton, T. G. (2013). Food production vs. biodiversity: comparing organic and conventional agriculture. J. Appl. Ecol. 50, 355-364. doi: 10.1111/1365-2664.12035

Garibaldi, L. A., Steffan-Dewenter, I., Kremen, C., Morales, J. M., Bommarco, R., Cunningham, S. A., et al. (2011). Stability of pollination services decreases with isolation from natural areas despite honey bee visits. Ecol. Lett. 14, 1062-1072. doi: 10.1111/j.1461-0248.2011.01669.x

Gaston, K. J., and Fuller, R. A. (2008). Commonness, population depletion and conservation biology. Trends Ecol. Evol. 23, 14-19. doi: 10.1016/j.tree.2007.11.001

Geiger, F., Bengtsson, J., Berendse, F., Weisser, W. W., Emmerson, M., Morales, M. B., et al. (2010). Persistent negative effects of pesticides on biodiversity and biological control potential on European farmland. Basic Appl. Ecol. 11, 97-105. doi: 10.1016/j.baae.2009.12.001

Gillson, L., Dawson, T. P., Jack, S., and McGeogh, M. A. (2013). Accommodating climate change contingencies in conservation strategy. Trends Ecol. Evol. 28, 135-142. doi: 10.1016/j.tree.2012.10.008

Gilroy, J. J., Edwards, F. A., Uribe, C. A. M., Haugaasen, T., and Edwards, D. P. (2014). Surrounding habitats mediate the trade-off between land-sharing and land-sparing agriculture in the tropics. J. Appl. Ecol. 51, 1337-1346. doi: 10.1111/1365-2664.12284

Gonthier, D. J., Ennis, K. K., Farinas, S., Hsieh, H.-Y., Iverson, A. L., Batáry, P., et al. (2014). Biodiversity conservation in agriculture requires a multi-scale approach. Proc. R. Soc. B. 281:20141358. doi: 10.1098/rspb.20 14.1358

Grau, R., Kuemmerle, T., and Macchi, L. (2013). Beyond 'land sparing versus land sharing': environmental heterogeneity, globalization and the balance between 
agricultural production and nature conservation. Curr. Opin. Environ. Sust. 5, 477-483. doi: 10.1016/j.cosust.2013.06.001

Green, R. E., Cornell, S. J., Scharlemann, J. P. W., and Balmford, A. (2005). Farming and the fate of wild nature. Science 307, 550-555. doi: 10.1126/science.1106049

Hannah, L., Midgley, G. F., and Millar, D. (2002). Climate change-integrated conservation strategies. Global Ecol. Biogeogr. 11, 485-495. doi: 10.1046/j.1466822X.2002.00306.X

Hansen, A. J., and DeFries, R. (2007). Ecological mechanisms linking protected areas to surrounding lands. Ecol. Appl. 17, 974-988. doi: 10.1890/ 05-1098

Hanski, I. (2005). Shrinking World: Ecological Consequences of Habitat Loss. Oldendorf/Luhe: International Ecology Institute.

Hanski, I. (2011). Habitat loss, the dynamics of biodiversity, and a perspective on conservation. Ambio 40, 248-255. doi: 10.1007/s13280-011-0147-3

Hanski, I. (2015). Habitat fragmentation and species richness. J. Biogeogr. 42, 989-994. doi: 10.1111/jbi.12478

Hodgson, J. A., Kunin, W. E., Thomas, C. D., Benton, T. G., and Gabriel, D. (2010). Comparing organic farming and land sparing: optimizing yield and butterfly populations at a landscape scale. Ecol. Lett. 13, 1358-1367. doi: 10.1111/j.1461-0248.2010.01528.x

Hodgson, J. A., Moilanen, A., Wintle, B. A., and Thomas, C. D. (2011). Habitat area, quality and connectivity: striking the balance for effective conservation. J. Appl. Ecol. 48, 148-152. doi: 10.1111/j.1365-2664.2010. 01919.x

Hodgson, J. A., Thomas, C. D., Wintle, B. A., and Moilanen, A. (2009). Climate change, connectivity and conservation decision making: back to basics. J. Appl. Ecol. 46, 964-969. doi: 10.1111/j.1365-2664.2009.01695.x

Honnay, O., Verheyen, K., Butaye, J., Jacquemyn, H., Bossuyt, B., and Hermy, M. (2002). Possible effects of habitat fragmentation and climate change on the range of forest plant species. Ecol. Lett. 5, 525-530. doi: 10.1046/j.14610248.2002.00346.x

Jonsson, M., Bommarco, R., Ekbom, B., Smith, H. G., Bengtsson, J., CaballeroLopez, B., et al. (2014). Ecological production functions for biological control services in agricultural landscapes. Methods Ecol. Evol. 5, 243-252. doi: 10.1111/2041-210X.12149

Jonsson, M., Buckley, H. L., Case, B. S., Wratten, S. D., Hale, R. J., and Didham, R. K. (2012). Agricultural intensification drives landscape-context effects on host-parasitoid interactions in agroecosystems. J. Appl. Ecol. 49, 706-714. doi: 10.1111/j.1365-2664.2012.02130.x

Joppa, L. N., and Pfaff, A. (2011). Global protected area impacts. Proc. R. Soc. B 278, 1633-1638. doi: 10.1098/rspb.2010.1713

Jordbruksverket (2005). Äng-och Betesmarksinventeringen 2002-2004. Jönköping: Rapport 2005:1 (in Swedish with an English summary).

JRC (2012). The State of Soil in Europe. Ispra, JRC. ISBN 978-92-7922806-3.

Kamp, J., Urazaliez, R., Balmford, A., Donald, P. F., Green, R. Y., Lamb, A. J., et al. (2015). Agricultural development and the conservation of avian biodiversity on the European steppes: a comparison of land-sparing and land-sharing approaches. J. Appl. Ecol. 52, 1578-1587. doi: 10.1111/1365-2664.12527

Kleijn, D., Rundlöf, M., Scheper, J., Smith, H. G., and Tscharntke, T. (2011). Does conservation on farmland contribute to halting the biodiversity decline? Trends Ecol. Evol. 26, 474-481. doi: 10.1016/j.tree.2011.05.009

Kleijn, D., Winfree, R., Bartomeus, I., Carvalheiro, L. G., Henry, M., Isaacs, R., et al. (2015). Delivery of crop pollination services is an insufficient argument for wild pollinator conservation. Nat. Commun. 6, 7414. doi: 10.1038/ ncomms 8414

Koh, L. P., Levang, P., and Ghazoul, J. (2009). Designer landscapes for sustainable biofuels. Trends Ecol. Evol. 24, 431-438. doi: 10.1016/j.tree.2009.03.012

Kremen, C. (2015). Reframing the land-sparing/land-sharing debate for biodiversity conservation. Ann. N.Y. Acad. Sci. 1355, 52-76. doi: $10.1111 /$ nyas. 12845

Kuussaari, M., Bommarco, R., Heikkinen, R. K., Helm, A., Krauss, J., Lindborg, R., et al. (2009). Extinction debt: a challenge for biodiversity conservation. Trends Ecol. Evol. 24, 564-571. doi: 10.1016/j.tree.2009.04.011

Law, E. A., and Wilson, K. A. (2015). Providing context for the land-sharing and land-sparing debate. Conserv. Lett. 8, 404-413. doi: 10.1111/conl.12168

Leibold, M. A., Holyoak, M., Mouquet, N., Amarasekare, P., Chase, J. M., Hoopes, M. F., et al. (2004). The metacommunity concept: a framework for multi-scale community ecology. Ecol. Lett. 7, 601-613. doi: 10.1111/j.14610248.2004.00608.x

Lindenmayer, D. B., Franklin, J. F., and Fischer, J. (2006). General management principles and a checklist to guide forest biodiversity conservation. Biol. Conserv. 131, 433-443. doi: 10.1016/j.biocon.2006.02.019

Loos, J., Abson, D. J., Chappell, M. J., Hanspach, J., Mikulcak, F., Tichit, M., et al. (2014). Putting meaning back to "sustainable intensification." Front. Ecol. Environ. 12, 356-361. doi: 10.1890/130157

Macchi, L., Grau, H. R., Zelaya, P. V., and Marinaro, S. (2013). Trade-offs between land use intensity and avian biodiversity in the dry Chao of Argentina: a tale of two gradients. Agric. Ecosyst. Environ. 174, 11-20. doi: 10.1016/j.agee.2013.04.011

Mace, G. M., Norris, K., and Fitter, A. H. (2012). Biodiversity and ecosystem services: a multilayered relationship. Trends Ecol. Evol. 27, 19-26. doi: 10.1016/j.tree.2011.08.006

Macfadyen, S., Cunningham, S. A., Costamanga, A. C., and Schellhorn, N. A. (2012). Managing ecosystem services and biodiversity conservation in agricultural landscapes: are the solutions the same? J. Appl. Ecol. 49, 690-694. doi: 10.1111/j.1365-2664.2012.02132.x

Maes, J., Barbosa, A., Baranzelli, C., Zulian, G., Batista E Silva, F., Vandecasteele, I., et al. (2015). More green infrastructure is required to maintain ecosystem services under current trends in land-use change in Europe. Landscape Ecol. 30, 517-534. doi: 10.1007/s10980-014-0083-2

Maiorano, L., Amori, G., Montemaggiori, A., Rondinini, C., Santini, L., Saura, S., et al. (2015). On how much biodiversity is covered in Europe by national protected areas and by the Natura 2000 network: insights from terrestrial vertebrates. Conserv. Biol. 29, 986-995. doi: 10.1111/cobi. 12535

Mattison, E. H. A., and Norris, K. (2005). Bridging the gaps between agricultural policy, land-use and biodiversity. Trends Ecol. Evol. 11, 610-616. doi: 10.1016/j.tree.2005.08.011

Menalled, F. D., Costamagna, A. C., Marino, P. C., and Landis, D. A. (2003). Temporal variation in the response of parasitoids to agricultural landscape structure. Agric. Ecosyst. Environ. 96, 29-35. doi: 10.1016/S01678809(03)00018-5

Mitchell, M. G. E., Suarez-Castro, M. F., Martinez-Harms, M., Maron, M., McAlpine, C., Gaston, K. J., et al. (2015). Reframing landscape fragmentation's effects on ecosystem services. Trends Ecol. Evol. 30, 190-198. doi: 10.1016/j.tree.2015.01.011

Mueller, N. D., Gerber, J. S., Johnston, M., Ray, D. K., Ramankutty, N., and Foley, J. A. (2012). Closing yield gaps through nutrient and water management. Nature 480, 254-257. doi: 10.1038/nature11420

Navarro, L. M., and Pereira, H. M. (2012). Rewilding abandoned landscapes in Europe. Ecosystems 15, 900-912. doi: 10.1007/s10021-0129558-7

Norris, K., Potts, S. G., and Mortimer, S. R. (2010). "Ecosystem services and food production," in Ecosystem Services, eds R. E. Hester and R. M. Harrison (Cambridge: Issues in Environmental science and technology, RSC), 52-69.

Öckinger, E., and Smith, H. G. (2006). Landscape composition and habitat area affects butterfly species richness in semi-natural grasslands. Oecologia 149, 526-534. doi: 10.1007/s00442-006-0464-6

Öckinger, E., and Smith, H. G. (2007). Semi-natural grasslands as population sources for pollinating insects in agricultural landscapes. J. Appl. Ecol. 44, 50-59. doi: 10.1111/j.1365-2664.2006.01250.x

Öckinger, E., and Smith, H. G. (2008). Do corridors promote dispersal in grassland butterflies and other insects? Landsc. Ecol. 23, 27-40. doi: 10.1007/s10980-0079167-6

Ojanen, S. P., Nieminen, M., Meyke, E., Pöyry, J., and Hanski, I. (2013). Longterm metapopulation study of the glanville fritillary butterfly (Melitaea cinxia): survey methods, data management, and long-term population trends. Ecol. Evol. 3, 3713-3737. doi: 10.1002/ece3.733

Olsson, O., and Bolin, A. (2014). A model for habitat selection and species distribution derived from central place foraging theory. Oecologia 175, 537-548. doi: 10.1007/s00442-014-2931-9

Olsson, P. A., and Ödman, A. M. (2014). Natural establishment of specialist plant species after topsoil removal and soil perturbation in degraded calcareous sandy grassland. Restor. Ecol. 22, 49-56. doi: 10.1111/rec.12024 
Palomo, I., Montes, C., Martín-Lopéz, B., González, J. A., Carcía-Llorente, M., Alcorlo, P., et al. (2014). Incorporating the social-ecological approach in protected areas in the Anthropocene. BioScience 64, 181-191. doi: 10.1093/biosci/bit033

Park, M. A., Blitzer, E. J., Gibbs, J., Losey, J. E., and Danforth, B. N. (2015). Negative effects of pesticides on wild bee communities can be buffered by landscape context. Proc. R Soc. B 282:20150299. doi: 10.1098/rspb.2015.0299

Paul, C., and Knoke, T. (2015). Between land sharing and land sparing - what role remains for forest management and conservation? Int. Forestry Rev. 17, 210-230. doi: 10.1505/146554815815500624

Pauw, A. (2007). Collapse of a pollination web in small conservation areas. Ecology 88, 1759-1769. doi: 10.1890/06-1383.1

Perfecto, I., and Vandermeer, J. (2010). The agroecological matrix as alternative to the land-sparing/agriculture intensification model. Proc. Natl. Acad. Sci. U.S.A. 107, 5786-5791. doi: 10.1073/pnas.0905455107

Phalan, B., Balmford, A., Green, R. E., and Scharlemann, J. P. W. (2011a). Minimising the harm to biodiversity of producing more food globally. Food Policy 36, S62-S71. doi: 10.1016/j.foodpol.2010.11.008

Phalan, B., Onial, M., Balmford, A., and Green, R. H. (2011b). Reconciling food production and biodiversity conservation: land sharing and land sparing compared. Science 333, 1289-1291. doi: 10.1126/science.1208742

Ponisio, L. C., M'Gonigle, L. K., Mace, K. C., Palomino, J., de Valpine, P., and Kremen, C. (2015). Diversification practices reduce organic to conventional yield gap. Proc. R. Soc. B 282:20141396. doi: 10.1098/rspb.2014.1396

Pressey, R. L. (1994). Ad hoc reservations: Forward or backward steps in developing representative reserve systems? Conserv. Biol. 8, 662-668. doi: 10.1046/j.15231739.1994.08030662.x

Purschke, O., Schmid, B. C., Sykes, M. T., Poschlod, P., Michalski, S. G., Durka, W., et al. (2013). Contrasting changes in taxonomic, phylogenetic and functional diversity during a long-term succession: insights into assembly processes. J. Ecol. 101, 857-866. doi: 10.1111/1365-2745.12098

Pywell, R. F., Heard, M. S., Woodcock, B. A., Hinsley, S., Ridding, L., Nowakowski, M., et al. (2015). Wildlife-friendly farming increase crop yield: evidence for ecological intensification. Proc. R. Soc. B 282:20151740. doi: 10.1098/rspb.2015.1740

Quinn, J. E., Brandle, J. R., and Johnson, R. J. (2012). The effects of land sparing and wildlife-friendly practices on grassland bird abundance within organic farming. Agric. Ecosyst. Environ. 161, 10-16. doi: 10.1016/j.agee.2012.07.021

Ramankutty, N., and Rhemtulla, J. (2012). Can intensive farming save nature? Front. Ecol. Environ. 10:455. doi: 10.1890/1540-9295-10.9.455

Ricketts, T. H. (2001). The matrix matters: effective isolation in fragmented landscapes. Am. Nat. 158, 87-99. doi: 10.1086/320863

Riibak, K., Reitalu, T., Tamme, R., Helm, A., Gerhold, P., Znamenskiy, S., et al. (2015). Dark diversity in dry calcareous grasslands is determined by dispersal ability and stress-tolerance. Ecography 38, 713-721. doi: 10.1111/ecog.01312

Rodrigues, A. S. L., Andelman, S. J., Bakarr, M. I., Boitani, L., Brooks, T. M., Cowling, R. M., et al. (2004). Effectiveness of the global protected area network in representing species diversity. Nature 428, 640-643. doi: 10.1038 /nature 02422

Rösch, V., Tscharntke, T., Scherber, C., Batáry, P., and Osborne, J. (2013). Landscape composition, connectivity and fragment size drive effects of grassland fragmentation on insect communities. J. Appl. Ecol. 50, 387-394. doi: $10.1111 / 1365-2664.12056$

Rosenzweig, M. L. (1995). Species Diversity in Space and Time. Cambridge: Cambridge University Press. doi: 10.1017/cbo9780511623387

Rundlöf, M., Andersson, G. K. S., Bommarco, R., Fries, I., Hederström, V., Herbertsson, L., et al. (2015). Seed coating with a neonicotinoid insecticide negatively affects wild bees. Nature 521, 77-80. doi: 10.1038/nature14420

Rundlöf, M., Persson, A. S., Smith, H. G., and Bommarco, R. (2014). Late-season mass-flowering red clover increases bumble bee queen and male densities. Biol. Conserv. 172, 138-145. doi: 10.1016/j.biocon.2014.02.027

Rusch, A., Birkhofer, K., Bommarco, R., Smith, H. G., and Ekbom, B. (2014). Management intensity at field and landscape levels affects the taxonomic and functional structure of generalist predator communities. Oecologia 175, 971-983. doi: 10.1007/s00442-014-2949-Z

Rusch, A., Valantin-Morison, M., Sarthou, J.-P., and Roger-Estrade, J. (2010). Biological control of insect pests in agroecosystems: effects of crop management, farming systems, and seminatural habitats at the landscape scale: a review. Adv. Agron. 109, 219-259. doi: 10.1016/B978-0-12-385040-9. 00006-2

Sánchez-Fernández, D., and Abellán, P. (2015). Using null-models to identify under-represented species in protected areas: a case study using European amphibians and reptiles. Biol. Conserv. 184, 290-299. doi: 10.1016/j.biocon.2015.02.006

Sánchez-Fernández, D., Abellán, P., Picazo, F., Millán, A., Ribera, I., and Lobo, J. M. (2013). Do protected areas represent species' optimal climatic conditions? A test using Iberian water beetles. Divers. Distrib. 19, 1407-1417. doi: $10.1111 /$ ddi. 12104

Shackelford, G. E., Steward, P. R., German, R. N., Sait, S. M., and Benton, T. G. (2015). Conservation planning in agricultural landscapes: hotspots of conflict between agriculture and nature. Divers. Distrib. 21, 357-367. doi: 10.1111/ddi.12291

Schneider, M. K., Lüscher, G., Jeanneret, P., Arndorfer, M., Ammari, Y., Bailey, D., et al. (2014). Gains to species diversity in organically farmed fields are not propagated at the farm level. Nat. Commun. 5, 4151. doi: 10.1038/ncomms5151

Schwartz, M. W. (1999). Choosing the appropriate scale of reserves for conservation. Annu. Rev. Ecol. Syst. 30, 83-108. doi: 10.1146/annurev.ecolsys.30.1.83

Scott, J. M., Davis, F. W., McGhie, R. G., Wright, R. G., Groves, C., and Estes, J. (2001). Nature reserves: do they capture the full range of America's biological diversity? Ecol. Appl. 11, 999-1007. doi: 10.1890/10510761(2001)011[0999:nrdtct]2.0.co;2

Secretariat of the Convention of Biological Diversity (2008). A New Universal Global Alliance for Biodiversity Protection Established in Bonn. Montreal, QC. (Accessed May 30).

Seufert, V., Ramankutty, N., and Foley, J. A. (2012). Comparing the yields of organic and conventional agriculture. Nature 485, 229-U113. doi: $10.1038 /$ nature 11069

Smith, H. G., Birkhofer, K., Clough, Y., Ekroos, J., Olsson, O., and Rundlöf, M. (2014). "Beyond dispersal: the roles of animal movements in agricultural landscapes," in Animal Movement Across Scales, eds L.-A. Hansson and S. Åkesson (Oxford: Oxford University Press), 51-70.

Steffan-Dewenter, I., Bommarco, R., Holzschuh, A., Öckinger, E., Potts, S. G., and Riedinger, V. (2014). "The interface between conservation areas and agriculture: Functional spill-over and ecosystem services," in Scaling in Ecology and Biodiversity Conservation, eds K. Henle, S. G. Potts, W. E. Kunin, Y. G. Matsinos, J. Similä, J. D. Pantis, et al. (Sofia: Pensoft Publishers), 83-89.

Stehle, S., and Schultz, R. (2015). Agricultural insecticides threaten surface waters at the global scale. Proc. Natl. Acad. Sci. U.S.A. 112, 5750-5755. doi: $10.1073 /$ pnas. 1500232112

Stott, I., Soga, M., Inger, R., and Gaston, K. J. (2015). Land sparing is crucial for urban ecosystem services. Front. Ecol. Environ. 13, 387-393. doi: $10.1890 / 140286$

Tilman, D., Cassman, K. G., Matson, P. A., Naylor, R., and Polasky, S. (2002). Agricultural sustainability and intensive production practices. Nature 418, 671-677. doi: 10.1038/nature01014

Troupin, D., and Carmel, Y. (2014). Can agro-ecosystems efficiently complement protected area networks? Biol. Conserv. 169, 158-166. doi: 10.1016/j.biocon.2013.11.009

Tscharntke, T., Clough, Y., Wanger, T. C., Jackson, L., Motzke, I., Perfecto, I., et al. (2012a). Global food security, biodiversity conservation and the future of agricultural intensification. Biol. Conserv. 151, 51-59. doi: 10.1016/j.biocon.2012.01.068

Tscharntke, T., Klein, A. M., Kruess, A., Steffan-Dewenter, I., and Thies, C. (2005). Landscape perspectives on agricultural intensification and biodiversity ecosystem service management. Ecol. Lett. 8, 857-874. doi: 10.1111/j.14610248.2005.00782.x

Tscharntke, T., Tylianakis, J. M., Rand, T. A., Didham, R. K., Fahrig, L., Batáry, P., et al. (2012b). Landscape moderation of biodiversity patterns and processeseight hypotheses. Biol. Rev. 87, 661-685. doi: 10.1111/j.1469-185X.2011.00216.x

Valin, H., Sands, R. D., van der Mensbrugghe, D., Nelson, G. C., Ahammad, H., Blanc, E., et al. (2014). The future of food demand: understanding differences in economic models. Agric. Econ. 45, 51-67. doi: 10.1111/agec.12089

Verheijen, F. G. A., Jones, R. J. A., Rickson, R. J., and Smith, C. J. (2009). Tolerable versus actual soil erosion rates in Europe. Earth Sci. Rev. 94, 23-28. doi: 10.1016/j.earscirev.2009.02.003 
von Wehrden, H., Abson, D. J., Beckmann, M., Cord, A. F., Klotz, S., and Seppelt, R. (2014). Realigning the land-sharing/land-sparing debate to match conservation needs: considering diversity scales and land-use history. Landsc. Ecol. 29, 941-948. doi: 10.1007/s10980-0140038-7

Vörösmarty, C. J., McIntyre, P. B., Gessner, M. O., Dudgeon, D., Prusevich, A., Green, P., et al. (2010). Global threats to human water security and river biodiversity. Nature 467, 555-561. doi: 10.1038/nature09440

Wiens, J. A. (2009). Landscape ecology as a foundation for sustainable conservation. Landsc. Ecol. 24, 1053-1065. doi: 10.1007/s10980-0089284-x
Conflict of Interest Statement: The authors declare that the research was conducted in the absence of any commercial or financial relationships that could be construed as a potential conflict of interest.

Copyright (C) 2016 Ekroos, Ödman, Andersson, Birkhofer, Herbertsson, Klatt, Olsson, Olsson, Persson, Prentice, Rundlöf and Smith. This is an open-access article distributed under the terms of the Creative Commons Attribution License (CC BY). The use, distribution or reproduction in other forums is permitted, provided the original author(s) or licensor are credited and that the original publication in this journal is cited, in accordance with accepted academic practice. No use, distribution or reproduction is permitted which does not comply with these terms. 